\title{
Pengaturan Dan Implementasi Subsidi Biodiesel Indonesia-Uni Eropa Dalam Agreement On Subsidies And Countervailing Measures
}

\author{
Intan Griya Purnamasari \\ Magister Hukum Fakultas Hukum Universitas Islam Indonesia Yogyakarta Indonesia \\ Jln. Cik Di Tiro No. 1 Yogyakarta Indonesia \\ intangriya.purnamasari@gmail.com
}

\begin{abstract}
The World Trade Organization WTO plays a major role in carrying out rules on international trade such as the General Agreement on Tariffs and Trade (GATT). Meanwhile, the regulation regarding subsidies is regulated in Article XVI of the GATT and the Agreement on Subsidies and Countervailing Measures (SCM) in 1995. In international trade, subsidies are considered as a form of unfair competition, hence their use is limited. The objective of this research relates to the regulation and implementation of Indonesian biodiesel subsidies in the European Union which are reviewed based on SCM. The results of the study concluded that the European Union Commission found grants, tax breaks and raw materials below market prices for Indonesian biodiesel, which under Article 3 SCM, these subsidies are prohibited because grants, tax breaks and feedstocks below market prices are intended for Indonesian biodiesel exported products. Therefore, the application of subsidies by Indonesia to biodiesel is not in line with SCM.
\end{abstract}

Key Words: Biodiesel; SCM 1995; subsidies

\begin{abstract}
Abstrak
Organisasi Perdagangan Dunia WTO memainkan peran utama dalam menetapkan aturan internasional tentang perdagangan seperti Perjanjian Umum tentang Tarif dan Perdagangan (GATT). Sementara pengaturan mengenai subsidi diatur dalam Pasal XVI GATT dan Agreement on Subsidi and Countervailing Measures (SCM) tahun 1995. Dalam perdagangan internasional, subsidi dianggap sebagai bentuk persaingan curang, sehingga penggunaannya dibatasi. Pokok dalam penelitian ini berkaitan dengan pengaturan dan implementasi subsidi biodiesel Indonesia di Uni Eropa yang ditinjau berdasarkan SCM. Hasil penelitian menyimpulkan bahwa Komisi Uni Eropa menemukan hibah, potongan pajak dan bahan baku di bawah harga pasar bagi biodiesel Indonesia, yang berdasarkan Pasal 3 SCM, subsidi ini dilarang dikarenakan hibah, potongan pajak dan bahan baku di bawah harga pasar tersebut ditujukan untuk produk biodiesel Indonesia yang diekspor. Oleh karena itu, penerapan subsidi oleh Indonesia terhadap biodiesel belum sejalan dengan SCM.
\end{abstract}

Kata-kata Kunci: Biodiesel; SCM 1995; subsidi 


\section{Pendahuluan}

Industrialisasi dan kegiatan ekspor dan impor antar negara di seluruh dunia merupakan suatu keharusan di era globalisasi ini, bagaimana kepentingan profit oriented dijadikan sebagai tujuan utama dengan mengesampingkan aspek-aspek lain yang sebenarnya berimplikasi lebih besar dalam kehidupan manusia. Salah satu dari fungsi perdagangan internasional ialah menciptakan kesejahteraan sosial umat manusia, itu artinya bahwa ada misi sosial dari diterapkannya sistem perdagangan internasional itu sendi. ${ }^{1}$ Perdagangan internasional adalah merupakan sarana untuk melakukan pertukaran barang dan jasa internasional.

Pada 1995 terbentuk organisasi perdagangan dunia WTO (World Trade Organization). WTO berperan besar dalam mempromosikan perdagangan bebas dalam proses globalisasi. Tujuan utama dari didirikannya WTO merupakan sarana untuk mendorong dan mengembangkan liberalisasi perdagangan dan menyediakan sebuah sistem perdagangan dunia yang aman. Di samping itu, WTO berperan besar dalam menjalankan setiap peraturan yang telah ditetapkan dalam setiap perjanjian perdagangan dunia seperti Uruguay Round Second dan perjanjian pada GATT (General Agreement on Tarriffs and Trade). ${ }^{2}$

GATT merupakan perjanjian perdagangan multilateral yang berdasarkan mukadimahnya. Tujuan dari perjanjian ini adalah pengurangan substansial atas tarif dan hambatan perdagangan lainnya dan penghapusan perlakuan diskriminasi dalam perdagangan internasional. Salah satu prinsip perdagangan yang diatur dalam GATT adalah prinsip persaingan yang adil (fairness principle). Untuk menciptakan persaingan yang adil, GATT menetapkan ketentuanketentuan diantaranya yaitu pembatasan pemberian subsidi terhadap produk ekspor. ${ }^{3}$ Menurut Andreas F. Lowenfield menyatakan bahwa subsidi merupakan transfer kekayaan dari dana publik kepada suatu kelompok penerima manfaat tertentu, dimana dipercayai tidak dapat bertahan, atau setidaknya tidak dapat mempertahankan kedudukan mereka, jika hanya didasarkan pada kekuatan pasar semata. 4

Aturan mengenai subsidi diatur dalam Pasal XVI GATT dan lebih lanjut diatur dalam Agreement on Subsidies and Countervailing Measures 1995 (SCM). Di dalam SCM mengatur lebih rinci mengenai subsidi dan tindakan yang dapat

\footnotetext{
${ }^{1}$ Satria Unggul Wicaksana Prakasa, "Perdagangan Internasional Dan Ham: Relasinya Dengan Sustainable Development”, Jurnal Hukum Novelty, Vol. 9, No. 1, Februari 2018, hlm. 37.

${ }^{2}$ Ibid, hlm. 48.

3 Tri Harnowo, "Mengenal Subsidi yang Dilarang dalam Perdagangan Internasional", https://www.hukumonline.com/klinik/detail/ulasan/lt5dd25ec134914/mengenal-subsidi-yang-dilarang-dalamperdagangan-internasional/

4 Andreas F. Lowenfield, International Economic Law, Second Edition, Oxford University Press, New York, 2008, hlm. 216.
} 
diambil oleh negara anggota yang dirugikan akibat adanya produk ekspor yang disubsidi negara lain. Pengertian daripada subsidi tepatnya diatur dalam Pasal 1 ayat (1) SCM, yang mana telah memberikan definisi umum mengenai subsidi yang akan menjadi acuan dalam penentuan apakah subsidi tersebut diperbolehkan atau tidak. Berdasarkan Pasal 1 ayat (1) SCM subsidi dapat dikategorikan menjadi beberapa macam, yaitu: hibah pemerintah, pinjaman pemerintah, pemasukan modal pemerintah, penjaminan pinjaman oleh pemerintah, insentif fiskal seperti kredit pajak, penyediaan barang dan jasa oleh pemerintah, serta pembelian barang oleh pemerintah diluar infrastruktur umum, mekanisme pendanaan oleh pemerintah kepada lembaga privat yang melakukan tindakan tersebut, dukungan pendapatan dan dukungan harga. ${ }^{5}$

Menurut Mitsuo Mathushita, berdasarkan ketentuan Pasal 1 dan Pasal 2 SCM, maka terdapat tiga elemen dasar dalam menentukan subsidi berdasarkan SCM, yaitu: subsidi harus merupakan suatu konstribusi keuangan dari pemerintah atau badan publik, subsidi tersebut harus memberikan manfaat, subsidi harus spesifik kepada penerima tertentu. ${ }^{6}$ Pada dasarnya di dalam SCM mengklasifikasikan subsidi dalam 2 bentuk utama, yakni subsidi yang dilarang (prohibited subsidies) sebagaimana diatur dalam Bagian II SCM dan subsidi yang dapat dikenakan tindakan (actionable subsidies) sebagaimana diatur dalam Bagian III SCM. Sebenarnya masih terdapat satu kategori subsidi yaitu subsidi yang tidak dapat dikenakan tindakan sebagaimana diatur dalam Bagian IV SCM. Akan tetapi subsidi ini telah berakhir dan menjadi tidak berlaku, dikarenakan tidak adanya negara anggota yang menyetujui perpanjangan keberlakuan ketentuan ini. ${ }^{7}$

Subsidi dianggap sebagai salah satu bentuk persaingan yang curang, khususnya dalam dunia perdagangan internasional. Oleh karenanya, penggunaan subsidi dibatasi agar tidak menimbulkan hal-hal yang dapat menganggu negara lain. Perlakuan ini merupakan kebijaksanaan pemerintah untuk meningkatkan perekonomian dalam negerinya, tetapi dalam praktek seringkali menimbulkan masalah di dalam perdagangan internasional. ${ }^{8}$ Seperti halnya permasalahan Uni Eropa (UE) dengan Indonesia terkait minyak kelapa sawit / biodiesel. Berbagai macam kebijakan yang dilakukan berupaya untuk menahan laju ekspor Crude Palm Oil (CPO) ke UE. Disisi lain ada juga upaya UE untuk mendorong pertumbuhan minyak nabati domestik. Dengan begitu maka menjadikan concern petani Eropa dan

\footnotetext{
5 Tri Harnowo, Loc. Cit.

${ }^{6}$ Mitsuo Matsushita, et.al, The World Trade Organization, Law, Practice, and Policy, Third Edition, Oxford University Press, United Kingdom, 2017, hlm. 305.

7 Tri Harnowo, Loc. Cit.

${ }^{8}$ H. Simatupang, "Aspek Hukum Pemberian Subsidi oleh Negara di Dalam Lalu Lintas Perdagangan Internasional", Pusjianbang Departemen Hukum dan HAM RI, Lex Jurnalica, Vol. 6. No. 1, Desember 2008, hlm. 14.
} 
menjadi input bagi Parlemen Eropa untuk melindungi kepentingan domestiknya. Namun jika diamati, produksi domestik minyak nabati UE adalah sebesar 2,8 persen, sedangkan laju pertumbuhan konsumsinya jauh lebih besar, yakni 4,8 persen. Sehingga jelas bahwa jumlah konsumsi jauh lebih tinggi daripada jumlah produksi, dengan begitu sudah semestinya dibutuhkan tambahan adanya biodiesel.

Menurut UE, adanya permasalahan antara UE dengan Indonesia dikarenakan adanya subsidi yang diberikan pemerintah Indonesia dalam produksi biodiesel. Dimana perlakuan pemerintah Indonesia dengan memberikan subsidi kelapa sawit sebagai produk ekspor dapat menghambat produsen domestik Uni Eropa. Dengan begitu dapat dipahami bahwasanya disatu sisi peran subsidi sangatlah dibutuhkan, mengingat masih banyak kelompok yang tidak dapat mempertahankan kedudukannya jika didasarkan pada kekuatan pasar. Namun disisi lain juga haruslah didasarkan pada aturan yang sudah berlaku. Hal tersebut dikarenakan, jangan sampai adanya subsidi justru dapat menghambat perdagangan internasional. Maka penulis berniat ingin melakukan analisi terkait Pengaturan dan Implementasi subsidi oleh Indonesia ditinjau dalam Agreement on Subsidies and Cuntervailing Measures 1995 - WTO.

\section{Rumusan Masalah}

1. Bagaimana Pengaturan Subsidi dalam Agreement on Subsidies and Countervailing Measures 1995 (SCM) dan World Trade Organization (WTO)?

2. Bagaimana pengembangan kebijakan Biodiesel berbasis minyak kelapa sawit (CPO) di Indonesia?

3. Bagaimana Implementasi Subsidi oleh Indonesia dalam kebijakan ekspor Biodiesel ditinjau dari Agreement on Subsidies and Countervailing Measures 1995 (SCM)?

\section{Tujuan Penelitian}

1. Pengaturan Subsidi dalam Agreement on Subsidies and Countervailing Measures 1995 (SCM) dan World Trade Organization (WTO).

2. Pengembangan kebijakan Biodiesel berbasis minyak kelapa sawit (CPO) di Indonesia.

3. Implementasi Subsidi oleh Indonesia dalam kebijakan ekspor Biodiesel ditinjau dari Agreement on Subsidies and Countervailing Measures 1995 (SCM).

\section{Metode Penelitian}

Kajian ini merupakan hasil penelitian individu dengan judul "Penganturan dan implementasi subsidi terhadap kasus biodiesel Indonesia dengan Uni Eropa 
ditinjau dalam agreement on subsidies and countervailing measures 1995". Penelitian ini merupakan penelitian hukum yuridis dan menggunakan metode pendekatan kasus. Penelitian ini adalah terkait dengan pengaturan subsidi dan implementasinya.

\section{Hasil Penelitian dan Pembahasan}

Pengaturan Subsidi dalam Agreement on Subsidies and Countervailing Measures 1995 (SCM) dan World Trade Organization (WTO)

Menurut Habib Nazir, subsidi merupakan cadangan keuangan dan sumbersumber daya lainnya untuk mendukung suatu kegiatan usaha atau kegiatan perorangan oleh pemerintah. Dimana menurut Huala Adolf dan A. Chandrawulan, subsidi adalah sebuah pembayaran oleh pemerintah untuk produsen, distributor dan konsumen bahkan masyarakat dalam bidang tertentu. ${ }^{9}$ Hal tersebut sejalan dengan Andreas F. Lowenfield, yang menyatakan bahwa subsidi ialah transfer kekayaan dari dana publik kepada suatu kelompok penerima manfaat tertentu, dimana dipercayai tidak dapat bertahan, atau setidaknya tidak dapat mempertahankan kedudukan mereka, kalau hanya didasarkan pada kekuatan pasar semata. ${ }^{10}$ Sehingga dapat dikatakan bahwa subsidi adalah pendanaan atau price support dari publik untuk suatu kelompok tertentu. Seperti halnya produsen, distributor, konsumen atau bahkan masyarakat dalam bindang tertentu. Dimana kelompok-kelompok tersebut belum mampu berdiri sendiri atau tidak dapat mempertahankan kedudukannya di dalam pasar. Sehingga peran pemerintah adalah untuk membantu mempertahakan kelompokkelompok tertentu untuk dapat bersaing mempertahankan kedudukannya di dalam pasar.

Pengaturan subsidi juga telah ditetapkan dalam Pasal XVI GATT, yang mana menyatakan bahwa, "If any contracting party grants or maintains any subsidy, including any form of income or price support, which operates directly or indirectly to increase exports of of any product form or to reduce imports of any product into, its territory, it shall notify the contracting parties..."11 hal tersebut dimaksudkan bahwa subsidi itu berasal dari adanya suatu pihak yang memberikan suatu dukungan terhadap pihak tertentu dalam bentuk pendapatan atau dukungan harga yang beroperasi secara langsung maupun tidak langsung dengan tujuan untuk meningkatkan ekspor dari segala produk.

${ }^{9}$ Huala Adolf \& A. Chandrawulan, Masalah-Masalah Hukum Dalam Perdagangan Internasional, Rajagrafindo Persada, Bandung, 1995, hlm. 64.

${ }^{10}$ Andreas F. Lowenfield, Op. Cit., hlm. 216.

11 Pasal XVI General Agreement on Tarriffs and Trade (GATT). 
Namun pengaturan subsidi justru lebih detail dan rinci diatur dalam The Agreement on Subsidies and Countervailing Measures 1995 (SCM). Di dalam perjanjian ini mengatur lebih rinci terkait dengan subsidi dan tindakan yang dapat diambil oleh negara anggota yang dirugikan akibat adanya produk ekspor yang disubsidi negara lainnya. Berdasarkan Pasal 1 General Provisions SCM menyebutkan bahwasanya, "there is a financial contribution by a government or any public body within the territory of a member reffered to in this agreement as government which is, (i) a government practice involves a direct transfer of funds (grants, loans, and equity infusion), potential direct transfer of funds or liabilities (loan guarantees), (ii) government revenue that is otherwise due is foregone or not collected, (iii) government provides goods or services other than general infrastructure or purchases goods,..."12 berdasarkan uraian di atas, maka subsidi dapat dibagi menjadi beberapa kategori, yaittu:
a. Hibah pemerintah (grant)
b. Pinjaman pemerintah (loan)
c. Pemasukan modal pemerintah (equity infusion)
d. Penjaminan pinjaman oleh pemerintah (loan guarantee)
e. Insentif fiskal seperti kredit pajak (tax credit)
f. Penyediaan barang dan jasa oleh pemerintah, serta pembelian barang oleh pemerintah diluar infrastruktur umum
g. Mekanisme pendanaan oleh pemerintah kepada lembaga privat yang melakukan tindakan a-f di atas,
h. Dukungan pendapatan (income subsidy)
i. Dukungan harga (price subsidy) ${ }^{13}$

Ketentuan di atas tidak dapat berdiri sendiri, melainkan harus memenuhi ketentuan bahwa subsidi tersebut harus bersifat spesifik sebagaimana ditentukan ditentukan di dalam Pasal 2 ayat (1) SCM yang menyatakan bahwa, " ... is specific to an enterprise or industry or a group of enterprises or industries...". ${ }^{14}$ Dengan begitu subsidi yang dimaksud adalah subsidi yang spesifik penerimanya, yaitu subsidi yang diberikan kepada suatu perusahaan, industri, kelompok perusahan atau kelompok industri. Sebagaimana yang telah ditentukan dalam SCM.

Pengaturan subsidi lebih lanjut juga diatur dalam SCM terkait dengan jenisjenis subsidi. Berdasarkan Bagian II SCM menjelaskan terkait subsidi yang dilarang (prohibited subsidies). ${ }^{15}$ Bagian III SCM menjelaskan terkait dengan subsido yang dapat dikenakan tindakan atau (actionable subsidies). ${ }^{16}$ Pada

\footnotetext{
12 Pasal 1 General Provisions on Agreement on Subsidies and Countervailing Measures 1995.

13 Tri Harnowo, Loc. Cit.

14 Pasal 2 ayat (1) Agreement on Subsidies and Countervailing Measures 1995.

15 Bagian II Agreement on Subsidies and Countervailing Measures 1995.

16 Bagian III Agreement on Subsidies and Countervailing Measures 1995.
} 
dasarnya, terdapat satu lagi kategori subsidi, yaitu subsidi yang tidak dapat dikenakan tindakan (non actionable subsidies). Hal tersebut diatur dalam Bagian IV SCM, namun ketentuan ini telah berakhir dan menjadi tidak berlaku dikarenakan tidak adanya negara anggota yang menyetujui perpanjangan. Subsidi kategori prohibited subsidies adalah memberikan daftar bentuk subsidi produk ekspor yang dilarang yang bersifat non exhaustive. Sedangkan dalam actionable subsidies tidak harus terhadap subsidi produk ekspor atau subsidi produk substitusi impor. Melainkan negara anggota dapat melakukan komplain terhadap setiap jenis subsidi sebagaimana ditentukan dalam ketentuan Pasal 1 ayat (1) SCM sepanjang yang bersangkutan dapat membuktikan adanya dampak kerugian ekonomi. ${ }^{17}$ Dengan begitu dapat disimpulkan apabila prohibited subsidies jelas dilarang karena berkaitan dengan subsidi dari pemerintah untuk perusahaan atau industri tertentu dalam hal subsidi produk ekspor atau subsidi produk substitusi impor. Sedangkan dalam actionable subsidies dapat dilarang apabila para pihak dapat membuktikan adanya kerugian ekonomi yang ditimbulkan akibatnya.

Dengan adanya produk bersubsidi, negara yang dirugikan dapat menempuh dua tindakan yaitu: menetapkan bea perimbangan (countervailing duty) terhadap produk bersubsidi tersebut dengan lebih dahulu melakukan inisiasi investigasi sendiri sebagaimana diatur dalam Bagian V SCM. Dan juga dapat menggunakan mekanisme penyelesaian sengketa WTO untuk memaksa negara pelanggar menyesuaikan perilaku kebijakannya sesuai dengan nilai-nilai WTO sebagaimana diatur dalam Pasal 4 dan Pasal 7 SCM. ${ }^{18}$

\section{Kebijakan Pengembangan Biodiesel Berbasis Minyak Sawit (CPO) di Indonesia}

Pengembangan biodiesel di Indonesia di dorong oleh Kebijakan Mandatori Biodiesel melalui Peraturan Menteri ESDM No. 32 Tahun 2008 tentang penyediaan, pemanfaatan, dan tata niaga bahan bakar nabati sebagai bahan bakar lain. Industri biodiesel sebagai sumber energi terbarukan semakin berkembang disebabkan oleh semakin meningkatnya kebutuhan Indonesia terhadap sumber energi sementara sumber energi dari minyak bumi ketersediaannya semakin menipis. Indonesia mengembangkan industry biodiesel berbahan baku minyak kelapa sawit karena komoditas kelapa sawit memiliki potensi terbesar untuk di olah menjadi biodiesel di Indonesia. Potensi tanaman kelapa sakit cukup tinggi dengan produktivitas 3,6-4 ton/ha dan didukung oleh luas lahan yang jauh

${ }^{17}$ Tri Harnowo, Loc. Cit.

18 Ibid. 
dibandingkan tanaman lainnya sehingga memiliki potensi sebesar 31.914 .476 kiloliter biodiesel. ${ }^{19}$

Pemerintah melakukan perubahan ketiga atas kebijakan mandatori biodiesel melalui Permen ESDM No. 12 Tahun 2015 dengan meningkatkan kewajiban minimal pemanfaatan sebagai campuran bahan bakar minyak menjadi 30 persen. Pemanfaatan biodiesel sebagai campuran bahan bakar minyak menjadi 30 persen. Keseriusan pemerintah dalam pengembangan industry biodiesel semakin ditunjukkan dengan dikeluarkannya Peraturan Menteri ESDM No. 26 Tahun 2015, yaitu badan usaha bahan nabati jenis biodiesel berhak memperoleh pembiayaan biobiesel dari Badan Pengelola Dana Perkebunan Kelapa Sawit. Dana tersebut merupakan pungutan atas ekspor komiditas perkebunan kelapa sawit dan turunnya serta iuran dari pelaku usaha perkebunan kelapa sawit sesuai dengan Peraturan Presiden No. 61 Tahun 2015. Dengan berbagai kebijakan yang telah di keluarkan tersebut, pemerintah menetapkan target produksi biodiesel pada 2015 sebesar 22.41 juta kiloliter. ${ }^{20}$

Berdasarkan perhitungan realisasi produksi biodiesel sesuai kebijakan mandatori biodiesel Indonesia hingga 2013 masih jauh dari target yang ditetapkan pemerintah dengan tingkat bleending rate 4.40 persen, sementara target yang ditetapkan 10 persen. Realisasi yang jauh dari target tersebut terkendala beberapa hal yang menjadi penghambat pengembangan biodiesel diantaranya biaya produksi yang tinggi dan tidak tersedianya pasar biodiesel karena hanya pertamina yang bertindak sebagai konsumen utama. Dengan begitu untuk mengatasi hal tersebut, perlu dilakukan analisis untuk mengetahui tingkat ketrercapaian produksi biodiesel berbahan baku minyak kelapa Indonesia dan alternative kebijakan untuk pengembangan biodiesel tersebut. ${ }^{21}$

\section{Implementasi Subsidi oleh Indonesia Ditinjau dalam Agreement on Subsidies and Countervailing Measures 1995 (SCM) dan World Trade Organization (WTO)}

Sejak 2015 hingga kuartal 2017, Indonesia menghadapi tekanan yang sangat besar khususnya dari Negara Uni Eropa (UE). Berbagai kebijakan yang dilakukan berupaya untuk menahan laju ekspor CPO ke UE. Disisi lain ada juga upaya UE untuk mendorong pertumbuhan minyak nabati domestik. Parlemen Eropa juga menghadapi tekanan yang cukup kuat dari Petani Rapeseed Oil (RSO) dan Sunflower Oil (SFO) di Uni Eropa. Hal ini kemudian menjadi concern petani Eropa dan menjadi input bagi Parlemen Eropa untuk melindungi kepentingan

${ }^{19}$ Khoiru Rizky Rambe, dkk, "Dinamika Kebijakan Pengembangan Biodiesel Berbahan Baku Kelapa Sawit", Jurnal Sosial Ekonomi Pertanian, Vol 15, No. 3, Oktober 2019, hlm. 240.

${ }^{20}$ Ibid.

${ }^{21}$ Ibid. 
domestiknya. Namun jika diamati, produksi domestik minyak nabati UE adalah sebesar 2,8 persen, sedangkan laju pertumbuhan konsumsinya jauh lebih besar, yakni 4,8 persen. Keadaan ini menciptakan widening gap atau kesenjangan yang semakin melebar antara produksi dan konsumsi. ${ }^{22}$ Dengan begitu dikarenakan jumlah konsumsi lebih besar daripada jumlah produksi maka tidak ada pilihan lain selain adanya kebijakan impor.

Permasalahan khususnya pada biodiesel asal Indonesia diganjar bea masuk antisubsidi (BMAS) sebesar 8\%-18\% oleh UE. Kebijakan tersebut resmi berlaku mulai Jumat 6 September 2019 dan ditetapkan secara definitif per 4 Januari 2020 dengan masa berlaku selama 5 tahun. Menurut Ketua Umum Asosiasi Produsen Biofuel Indonesia (Aprobi) mengakui, kebijakan UE tersebut memang akan memukul industri biodiesel Tanah Air. Pasalnya, hambatan tarif itu praktis akan membuat target ekspor biodiesel RI tahun ini tidak tercapai. Disisi lain, produk minyak nabati asal UE seperti minyak biji bunga matahari dan biji rapa kalah bersaing dari sisi harga dengan produk bahan bakar berbasis CPO itu. Sekretris Jenderal Gabungan Pengusaha Kelapa Sawit Indonesia (Gapki) mengatakan, tuduhan pengenaan subsidi kepada biodiesel asal RI oleh UE tidak berdasar. Hal tersebut dikarenakan selama ini UE mempermasalahkan penggunaan dana dari Badan Pengelola Dana Perkebunan Kelapa Sawit (BPDP-KS) dan pinjaman dari bank milik negara sebagai bentuk subsidi. Tetapi, dana dari BPDP itu bukan subsidi karena berasal dari pungutan ekspor juga. Sementara itu, pinjaman dari bank BUMN tentu tidak bisa disebut sebagai subsidi pemerintah, karena pinjaman yang diajukan murni pinjaman secara business to business. ${ }^{23}$

Pengenaan bea masuk merupakan tindakan perlawanan dari UE atas subsidi yang dinilai tidak adil dari Indonesia. Komisi UE melakukan penyelidikan terhadap tuduhan subsidi biodiesel Indonesia. Hasilnya, mereka menemukan bahwa produsen Indonesia mendapatkan manfaat dari subsidi, pajak, hingga akses terhadap bahan baku di bawah harga pasar. Dengan temuan itu, maka Komisi UE resmi memberlakukan bea masuk anti subsidi sebesar $8-18 \%{ }^{24}$

Berdasarkan hasil penyelidikan yang dilakukan oleh Komisi UE maka sebagaimana yang telah diatur dalam kesepakatan SCM bahwa sesuai dengan Pasal 1 ayat (1) menyatakan bahwa subsidi dapat dibagi menjadi beberapa

22 Pengusaha Kelapa Sawit Indonesia (GAPKI), "Analisis Ekspor CPO Indonesia ke Uni Eropa: Faktor Apa yang Mendorong Trend Positif?”, https://gapki.id/news/4268/analisis-ekspor-cpo-indonesia-ke-uni-eropafaktor-apa-yang-mendorong-trend-positif

${ }^{23}$ Yustinus Andri, "BMAS Biodiesel: Pengusaha Sawit Indonesia Mentahkan Tudingan UE Soal Subsidi", https://ekonomi.bisnis.com/read/20190726/12/1129006/bmas-biodiesel-pengusaha-sawit-indonesiamentahkan-tudingan-ue-soal-subsidi

24 CNN Indonesia, "Uni Eropa Resmi Pungut Bea Masuk 18 Persen Atas Sawit RI", https://www.cnnindonesia.com/ekonomi/20191210155013-85-455733/uni-eropa-resmi-pungut-bea-masuk-18persen-atas-sawit-ri 
kategori yaitu; hibah pemerintah, pinjaman pemerintah, pemasukan modal pemerintah, penjaminan pinjaman oleh pemerintah, insentif fiskal seperti kredit pajak, penyediaan barang dan jasa oleh pemerintah serta pembelian barang oleh pemerintah di luar infrastruktur umum, mekanisme pendanaan oleh pemerintah kepada lembaga privat, dukungan pendapatan dan dukungan harga. ${ }^{25}$ Dengan begitu, sesuai dengan hasil penyelidikan yang dilakukan Komisi UE adalah adanya subsidi dalam produk biodiesel Indonesia, terkhusus dalam hal hibah (grant), manfaat pajak (tax benefit), dan akses bahan baku di bawah harga pasar. Maka dari itu, hal-hal tersebut telah sesuai dengan Pasal 1 ayat (1) SCM.

Mengingat bahwa, sesuai dengan Pasal 3 SCM yang mengkategorikan prohibited subsidies adalah subsidi yang diberikan pemerintah yang pada dasarnya terdiri dari subsidi produk ekspor subsidi dan produk substitusi impor. ${ }^{26}$ Sebagaimana subsidi yang diatur dalam SCM, subsidi kategori prohibited subsidies otomatis memenuhi unsur spesifik sebagaimana dipersyaratkan. Annex 1 SCM memberikan daftar bentuk subsidi roduk ekspor yang dilarang. Dengan begitu, dikarenakan adanya hasil penyelidikan yang dilakukan Komisi UE dan menemukan adanya subsidi biodiesel Indonesia terkait gibah, manfaat pajak dan akses bahan baku di bawah harga pasar yang mana telah sesuai dengan Pasal 1 ayat (1) SCM. Di sisi lain, dikarenakan subsidi tersebut tergolong dalam subsidi yang dilarang sebagaimana sesuai dengan Pasal 3 SCM yang mana menyatakan, adanya larangan subsidi produk ekspor. Maka dapat disimpulkan bahwa dengan ditemukannya adanya subsidi terhadap produk biodiesel Indonesia oleh Komisi UE dan mengingat bahwa subsidi tersebut adalah subsidi produk ekspor, dengan begitu implementasi subsidi oleh Indonesia telah tidak sesuai dengan aturan yang sudah ditetapkan dalam Agreement on Subsidies and Contervailing Measures 1995 (SCM).

\section{Penutup}

Berdasarkan uraian di atas, maka dapat disimpulkan bahwa pengaturan subsidi telah diatur dalam Pasal XVI GATT dan lebih lanjut diatur dalam Agreement on Subsidies and Countervailing Measures 1995 (SCM). Terkhusus dalam Pasal 1 dan Pasal 3 SCM, yang mana menjelaskan terkait kategori subsidi dan subsidi yang dilarang. Pengembangan biodiesel di Indonesia didorong oleh Kebijakan Mandatori Biodiesel melalui Peraturan Menteri ESDM No. 32 Tahun 2008 tentang penyediaan, pemanfaatan, dan tata niaga bahan bakar nabati sebagai bahan bakar lain. Pemerintah melakukan perubahan ketiga atas kebijakan

\footnotetext{
25 Pasal 1 ayat (1) Agreement on Subsidies and Countervailing Measures 1995.

26 Pasal 3 Agreement on Subsidies and Countervailing Measures 1995.
} 
mandatori biodiesel melalui Permen ESDM No. 12 Tahun 2015 dengan meningkatkan kewajiban minimal pemanfaatan sebagai campuran bahan bakar minyak menjadi 30 persen. Hal tersebut didukung dengan dikeluarkannya Peraturan Menteri ESDM No. 26 Tahun 2015. Adanya kasus Uni Eropa dengan Indonesia terkait dengan minyak kelapa sawit / biodiesel / CPO (Crude Palm Oil). Dimana Komisi UE telah melakukan penyelidikan terhadap biodiesel Indonesia dan mendapati temuan bahwa adanya subsidi berupa hibah, manfaat pajak dan akses bahan baku dibawah harga pasar yang mana telah sesuai dengan Pasal 1 SCM. Subsidi tersebut jika ditinjau lebih lanjut berdasarkan Pasal 3 SCM menyimpulkan bahwa adanya subsidi yang dilarang. Pasalnya, adanya temuan hibah, manfaat pajak dan akses bahan baku dibawah harga pasar adalah subsidi untuk produk ekspor berupa produk biodiesel Indonesia. Dengan begitu, implementasi subsidi oleh Indonesia atas biodiesel telah tidak sesuai dengan aturan yang sudah ditetapkan dalam Agreement on Subsidies and Contervailing Measures 1995 (SCM).

\section{Daftar Pustaka}

\section{Buku}

Adolf, Huala \& Chandrawulan, A, Masalah-Masalah Hukum Dalam Perdagangan Internasional. Rajagrafindo Persada, Bandung, 1995.

Lowenfield, Andreas F. 2008. International Economic Law, Second Edition, Oxford University Press, New York, 2008.

Matsushita, Mitsuo et.a, The World Trade Organization, Law, Practice, and Policy, Third Edition, Oxford University Press, United Kingdom, 2017.

\section{Jurnal}

Rambe, Khoiru Rizky, dkk., “Dinamika Kebijakan Pengembangan Biodiesel Berbahan Baku Kelapa Sawit", Jurnal Sosial Ekonomi Pertanian, Vol. 15, No. 3, Oktober 2019.

Prakasa, Satria Unggul Wicaksana, "Perdagangan Internasional Dan Ham: Relasinya Dengan Sustainable Development", Jurnal Hukum Novelty, Vol. 9, No. 1. 2018.

Simatupang, H, "Aspek Hukum Pemberian Subsidi oleh Negara di Dalam Lalu Lintas Perdagangan Internasional", Pusjianbang Departemen Hukum dan HAM RI Lex Jurnalica Vol. 6, No. 1, 2008.

\section{Internet}

Andri, Yustinus, "BMAS Biodiesel: Pengusaha Sawit Indonesia Mentahkan Tudingan UE Soal Subsidi", https://ekonomi.bisnis.com/read/ 20190726/12/1129006/bmas-biodiesel-pengusaha-sawit-indonesiamentahkan-tudingan-ue-soal-subsidi 
CNN Indonesia, “Uni Eropa Resmi Pungut Bea Masuk 18 Persen Atas Sawit RI”, https: / / www.cnnindonesia.com/ekonomi/20191210155013-85-

455733/uni-eropa-resmi-pungut-bea-masuk-18-persen-atas-sawit-ri

Harnowo, Tri, "Mengenal Subsidi yang Dilarang dalam Perdagangan Internasional", https://www.hukumonline.com/klinik/detail/ulasan/lt5dd25ec134914/ mengenal-subsidi-yang-dilarang-dalam-perdagangan-internasional/

Pengusaha Kelapa Sawit Indonesia (GAPKI), "Analisis Ekspor CPO Indonesia ke Uni Eropa: Faktor Apa yang Mendorong Trend Positif?" https://gapki.id/news/4268/analisis-ekspor-cpo-indonesia-ke-unieropa-faktor-apa-yang-mendorong-trend-positif

\section{Peraturan}

General Agreement on Tarriffs and Trade (GATT).

The Agreement on Subsidies and Countervailing Measure (SCM) 1995. 